\title{
Polish Deadjectival Nouns as Nominalized Adverbs*
}

\begin{abstract}
The traditional description of Polish abstract nouns such as lekkość 'lightness' or jasność 'brightness' holds that they are formed with an adjectival root and the nominalizing suffix -ość. The paper considers an alternative analysis where -o-ść is a complex marker and such nominals go through an adverbial stage in their formation, rendering them $[[[A] \mathrm{Adv}] \mathrm{N}]$ structures, a possibility suggested by the fact that the $-o$ itself is an adverbial marker.
\end{abstract}

\section{Keywords}

derived -ość nouns, nomina essendi, adjectives, adverbs, Nanosyntax

\begin{abstract}
Abstrakt
Wedle tradycyjnego opisu, polskie abstrakcyjne rzeczowniki odprzymiotnikowe (nomina essendi), takie jak np. lekkość czy jasność, są zbudowane z przymiotnikowego tematu i przyrostka -ość. Artykuł rozważa alternatywną analizę, wedle której -o-ść jest przyrostkiem złożonym, a tworzone z nim rzeczowniki odprzymiotnikowe przechodzą przez etap
\end{abstract}

\footnotetext{
* I am indebted to two anonymous, albeit very helpful and encouraging, referees whose comments and suggestions helped me bring this paper to its present shape. For questions and comments I also thank the participants of FASL (MIT, May 2021), especially Anton Kukhto, and the $9^{\text {th }}$ Workshop on Nominalizations (University of Silesia \& Catholic University in Lublin, June 2021), both held online, where earlier versions of this paper were presented. I also thank Pavel Caha for an exchange about some of the issues related to the material reported here. Needless to say, the responsibility for this paper is solely mine.
} 
przysłówkowy, czyniąc je formami o strukturze [[[ A ] Adv ] N ]. Możliwość złożoności -o-ść sugeruje fakt, że -o jest przyrostkiem tworzącym przysłówki.

\section{Słowa kluczowe}

przyrostek -ość, nomina essendi, przymiotniki, przysłówki, nanosyntaktyka

\section{Introduction}

Polish abstract deadjectival nouns such as lekkość 'lightness' or jasność 'brightness' (nomina essendi) are typically described as formed by the addition of the suffix -ość to the stem of a qualitative adjective, e.g. lekk 'light' or jasn 'bright' (e.g. Grzegorczykowa and Puzynina 1999: 416-421; Szymanek 2015: 40-41). ${ }^{1}$ This paper explores the idea that this class of deadjectival nominals goes through an adverbial stage in their formation, a possibility suggested by the fact that -o itself is the adverbial formative, as in lekk-o 'light' or jasn-o 'brightly'. If splitting -ość into separate suffixes -o and -ść is the right morphological analysis and not a facetious coincidence, the result is that forms like lekkość should be represented as (1).

(1) $\left[_{\mathrm{N}}[\mathrm{Adv}[\mathrm{A} l e k k] o]\right.$ ść $]$

In what follows, this hypothesis is put to test by taking a closer look at the morphology and grammatical ingredients of adjectives that form the -ość nominals. The paper also identifies and discusses what appear to be two challenges to (1), namely (i) the missing forms of the -ość nominals with certain adjectives and adverbs and (ii) the existence of the other adverbial marker -e, as in źl-e 'bad, adv.', which is absent in the associated noun, like $z t$-ość.

The paper is organized as follows. Section 2 introduces the basic properties of -ość nominals. Section 3 discusses -ość nominals formed from the adjectives in the positive and the comparative degree (like większość 'majority'). Section 4 introduces the split -o-ść hypothesis, shows how grammatical features associated with - $o$ and -ść are lexicalized with phrasal spellout, and discusses adverbs for which there are corresponding adjectives but there are no corresponding -ość nominals. Section 5 discusses how the existence of the adverbs formed with - $e$ can be accommodated in the the split - $o$-ść analysis. Section 6 is the conclusion.

\footnotetext{
${ }^{1}$ The -osśc nominals usually cannot be formed from relational adjectives such as leśny 'of forest, arboreal', miejski 'urban', naftowy 'of petroleum' (cf. Grzegorczykowa 1979: 35).
} 


\section{Basic properties of -ość nominals}

The common property of all -ość nominals is that they are feminine, which is reflected by the NP-internal concord (with a demonstrative, a possessive pronoun, or an adjective) and the subject-verb agreement, as in (2a,b).

(2)
a. $T-a$
niezwykt-a
lekkość
okazat-a sie
DEM-FEM.SG unusual-FEM.SG
lightness.FEM.sG
turned.out-FEM.3sG
REFL
być tylko złudzeniem.
be.INF only illusion
'That unusual lightness turned out to be only an illusion.'
$\begin{array}{lll}\text { b. } & \text { twoj- } a \quad z b y t & \text { czest- } a \\ \text { DEM-FEM.SG your-FEM.SG too frequent-F } & \text { yoo } \\ \text { doprowadzit- } a \text { wszystkich do szatu. } \\ \text { drove-FEM.3sG everybody to madness }\end{array}$
'Your way too frequent submissiveness drove everybody mad.'

The -ość nominals are fairly productively formed from adjectives in the positive degree (e.g. lekk-i-lekk-ość) and a few nouns, listed in (3)-(4), are formed from the adjectives in both the positive and the comparative degree.

(3) a. mat-y 'small-Msc' - mat-ość 'littleness'

b. wysok-i 'tall-MSc' - wysok-ość 'height'

c. wielk-i 'large-MSc' - wielk-ość 'size'

d. lekk-i 'light' - lekk-ość 'lightness'

(4) a. mniejsz-y 'smaller-MSC' - mniejsz-ość 'minority'

b. wyższ-y 'taller-MSC' - wyższ-ość 'superiority'

c. większ-y 'larger-MSC' - większ-ość 'majority'

d. lizejsz-y 'lighter' - lizejsz-ość 'lightness'

While the meaning of the -ość nouns is predominantly consistent with the meaning of the associated adjectival root, the meaning of some nouns is to a certain extent idiosyncratic. For instance, the noun matość from (3a) applies to a small size as well as moral pettiness, while the adjective maty does not refer to the lack of morals. In turn, as seen in (4), the forms based on the comparative adjectives that denote physical properties are all nouns of abstract properties.

The -ość nominals can also be formed with adjectives derived from verbs, adverbs, and nouns, in which case the adjective-forming affix is preserved in the nominal. This is seen for instance in Table 1 in nouns based on the deverbal adjectives formed with -liw (e.g. koch-liw-ość 'amorousness') and - $t$ (e.g. $d b a-t$-ość 'attention'), in nouns based on deadverbial adjectives formed with -ow (e.g. natychmiast-ow-ość 'immediacy'), or in nouns based on the adnominal adjectives formed with -sk (e.g. amator-sk-ość 'amateurship', car-sk-ość 'tsarism'). 
Table 1. Adjectivizing affixes in -ość nominals

\begin{tabular}{lll}
\hline base & $\mathrm{A}$ & $\mathrm{N}$ \\
\hline koch-a-ć & koch-liw-y & koch-liw-ość \\
'love, v.' & 'amorous' & 'amorousness' \\
dbać & dba-1-y & dba-ł-ość \\
'take care, v.' & 'attentive' & 'attention' \\
natychmiast 'immediately, & natychmiast-ow-y 'immediate' & natychmiast-ow-ość \\
adv.' & & 'immediacy' \\
amator & amator-sk-i & amator-sk-ość \\
'amateur, n.' & 'amateurish' & 'amateurship' \\
car & car-sk-i & car-sk-ość \\
'tsar, n.' & 'tsarist' & 'tsarism' \\
\hline
\end{tabular}

The denominal adjectives with the -sk affix that can easily form -ość nominals include also place names, like the ones in Table 2.

Table 2. Adjectivizing -sk affix in -ossć nominals

\begin{tabular}{lll}
\hline base N (place) & $\mathrm{A}$ & $\mathrm{N}$ \\
\hline Warszawa & warszaw-sk-i & warszaw-sk-ość \\
'Warsaw' & 'Warsaw' & 'Warsawness' \\
Anglia & angiel-sk-i & angiel-sk-ość \\
'England' & 'English' & 'Englishness' \\
Poznań & poznań-sk-i & poznań-sk-ość \\
& 'Poznanian' & 'Poznańness' \\
\hline
\end{tabular}

While the roots of -sk adjectives can show mild allomorphy in front of -sk as in (5) or can be followed by an inner derivational suffix as in (6) we do not observe allomorphy of the morpheme directly followed by -ość, as e.g. in rosyj-sk-ość 'Russiannes', ameryka-ń-sk-ossć 'Americanness', or europ-ej$s k$-ość 'Europeanness'.

(5) a. Rosja 'Russia' - rosyj-sk-i 'Russian'

b. Francja 'France' - francu-sk-i 'French'

c. Wtochy 'Italy' - wto-sk-i 'Italian'

(6) a. Ameryka 'America' - ameryka-ń-sk-ość 'Americanness'

b. Europa 'Europe' - europ-ej-sk-i 'European' 
Likewise, the addition of the -ość to simplex stems (bare roots), as in biat-y 'white' - biat-ość 'whiteness' or in (3)-(4), does not trigger root allomorphy either. ${ }^{2}$

The overall picture is that the addition of the -ość affix to the adjectival stem does not result in the change of its morphological shape like morpheme reduction or allomorphy, no matter if the adjectival stem includes an adjectival root or is derived from a verb, adverb, or a noun. This observation applies both to the -ość nouns based on positive degree as well as the few nouns based on the comparative degree, which is discussed in the following section.

\section{Nouns formed from adjectives in the positive and comparative degree}

Morphologically, Polish adjectives consist of a stem that is followed by a portmanteau gender, number, and case agreement marker. The agreement marker is irrelevant to the purposes of this paper and the adjective forms used in what follows are all marked with the masculine singular nominative suffix $-i / y{ }^{3}$ What is relevant is the shape of the stem since the adjectives in the positive degree fall into three classes.

The first two classes have complex stems, which comprise a root that is followed either by $-n$ or $-k$. The examples of the $-n$ class include the following:

(7) jas- $n-y$ 'bright', mar-n-y 'miserable', świet- $n-y$ 'superb', intym-n-y 'intimate', przyjem-n-y 'pleasant', popular-n-y 'popular', intrat- $n-y$ 'lucrative', wzajem-n-y 'reciprocal', pazer- $n-y$ 'greedy', okrop- $n-y$ 'horrible'

The $-n$ affix can be added to nominal roots - or to be precise, to roots that are either syncretic with nominal roots or are allomorphs - as in barw-a 'color-FEM.NOM' - barw- $n-y$ 'colorful' or gtos 'voice' - głoś-n- $y$ 'loud'. For this reason $-n$ is sometimes described as an affix that forms denominal adjectives along more typical adjectivizing affixes that attach to nominal roots like -sk, -yst (e.g. gór-a 'mountain-FEM.NOM, n.) - gór-sk-i 'mountain, adj.,

${ }^{2}$ An anonymous reviewer of a conference abstract of this paper points out that Polish differs with this respect from Czech, where instances of root allomorphy before the -ost nominalizer are sometimes attested. For example, the root of bèl-ost 'whiteness' is different than the root of the adjective bil-y' 'white'. I have not managed to find similar cases of root (or affix) allomorphy in Polish in front of -ość.

${ }^{3}$ The MSC.SG.NOM marker - $i$ comes after soft (palatalized) consonants ( $n$ [n], śs]) as well as after $l, k, g$ (e.g. $t a[n]-i$ 'cheap', gę[c]- $i$ 'goose, adj., bawol- $i$ 'buffalo, adj., lekk-i 'light', drog- $i$ 'expensive'); $-y$ comes after hard as well as certain soft consonants like $c$ [ts] (e.g. $b o \dot{z}-y$ 'divine', dobr-y 'good', gorac- $y$ 'hot'). 
górz-yst-y 'mountainous') or -ow (e.g. pobrzeb 'funeral, n.' - pogrzeb-ow-y 'funeral, adj'.). ${ }^{4}$ However, it cannot be treated as an exclusively adjectivizing marker for nominal roots since it also gets added to canonical adjectival roots like mar- $n-y$ 'miserable' or jas- $n-y^{5}$

The $-k$ class is illustrated with the following examples:

(8) lek-k-i 'light', cięz- $k-i$ 'heavy', wąs- $k-i$ 'narrow', szero- $k-i$ 'wide', wys-ok-i 'tall', $n i s-k-i$ 'short', mięk-k-i 'soft', gięt- $k-i$ 'flexible', gład- $k-i$ 'smooth', $s z y b-k-i$ 'fast' The stems of the third class, shown in (9), have a root without a suffix. ${ }^{6}$

(9) mat- $y$ 'small', mtod- $y$ 'young', star- $y$ 'old', duz-y 'large', dobr-y 'good', $z t-y$ 'bad', blad-y 'pale', grub-y 'fat', chud-y 'slim', czyst-y 'clean', drog-i 'expensive'

In turn, in the comparative degree, Polish has two morphological classes: the $-e j-s z$ class and the - $s z$ class, and both classes can show suppletive allomorphy of the root, as illustrated with the following:

(10) a. jas- $n-y$ 'bright' - jaś-ni-ej-sz-y 'brighter'

b. mat-y 'small' - mni-ej-sz-y 'smaller'

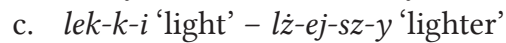

(11) a. mtod- $y$ 'young' - mlod-sz-y 'younger'

b. gład- $k-i$ 'smooth' - gład-sz-y 'smoother'

c. wys-ok-i 'tall' - wyz-sz-y 'taller'

d. wiel- $k-i$ 'large' - więk-sz-y 'larger'

${ }^{4}$ For a list and discussion of affixes that form denominal and deverbal adjectives see Post (1986) and Szymanek (1985, 1996, 2015).

${ }^{5}$ This also shows up in a neologism involving an adjectival root smart- $n-y$ 'smart, clever', a recently adaptated loanword from English, which co-exists with the nominal smart-n-ość 'smartness', as for instance in the excerpt retrieved from the Internet: "(...) do smartności obywatelskiej dotaczyła smartność technologiczna" 'technological smartness has joined the civic smartness' (https://wspolnota.org.pl/news/milowy-krok-w-lwowku-slaskim. Accessed: August $19^{\text {th }}$ 2021). The fact that $-n$ attaches to more than one type of roots is well known and shows up also within the denominal class: it is easily found in a subset of qualitative as well as relational adjectives (a distinction proposed for Polish in Gawełko 1976 and Szymanek 1985; for a detailed discussion see especially Szymanek 2015: 79-100). The first show the properties of canonical adjectives and are gradable, e.g. gtos 'voice' - głoś- $n-y$ 'loud', the second keep the property reading of the nominal base and are non-gradable, e.g. las 'forest' - leś- $n$ - $y$ 'of forest'.

${ }^{6}$ All three classes can also take negtive prefixes, e.g. nie-real-n-y 'unreal', bez-won- $n$ -

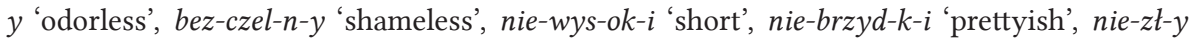
'quite nice', nie-drog-i 'inexpensive'. The presence of the prefix limits but doesn't exclude the possibility to form the -ość nominal, e.g. zt-ość 'anger' - *nie-zt-ość but czyst-ossć 'cleanliness' - nie-czyst-ość 'impurity', czel-n-ość 'arrogance' - bez-czel-n-ość 'insolence', wrażliwość 'sensitivity' - nad-wrażliwość 'hypersensitivity'. This suggests that the prefix in principle doesn't morphologically block the formation of the -ość nominal and the unattested forms are paradigm gaps. These are also found with unprefixed forms of adjectives, e.g. $d u \dot{z}-y$ 'large' *duż-ość, brunat- $n$ - $y$ 'brown' - *brunat- $n$-ość, tad-n-y 'pretty' - *tad-n-ość (where the asterisk indicates unattestedness rather than ill-formedness). 
As seen in the examples in (4), the entire stem of the comparative adjective is preserved in front of the nominalizing -ość suffix, just like in the case of the adjectives in the positive degree. The symmetry between how the abstract nouns are formed with positive and comparative stems will be relevant to our discussion of the features that are realized by the -ość affix.

What is relevant for our purpose is the fact that all three classes of the positive adjective can form adverbs with the suffix - $o$ while preserving the shape of the stem, as can be illustrated with e.g. jas-n-o 'brightly', lek-k-o 'lightly', wys-ok-o 'highly', mat-o 'a little', mtod-o 'young'. The fact that the adverbs are formed with - $o$ opens up the possibility to analyze the traditional nominalizer -ość as consiting of the - $o$ and a separate consonantal marker -ść.

Before we explore the idea that $-o$ is an affix let us consider an immediate alternative, namely that it is an epenthetic vowel inserted between -ść and a consonantal stem in order to avoid a three consonant cluster. Such an option, however, is unlikely for four reasons. One, Polish does not have a rule of $o$-insertion that is attested in other contexts. Two, Polish is well known for allowing clusters with more than two consonants across a stemsuffix boundary, e.g. in pośmiert-n-y 'post-mortem', częst-sz-y 'more frequent', warszaw-sk-i 'Warsaw, adj., wejś-ć 'enter'. 'Three, Polish tolerates consonant sequences with ść both stem-internally as in sierść [cerctc] 'animal hair', mści-ć [møtcitc] 'revenge, v.', kiepści-ut-ko [kjepctciutko] 'badly, dim.', as well as at a prefix-stem boundary as in ob-ściskiwa-ć [opctçisk ${ }^{\mathrm{j}} \mathrm{ivat}$ ] $]$ 'embrace', pod-ściela-ć [potctçlatc] 'make the bed'. Four, o does not get inserted before ść within a syllable, as in the complex onset in mścimy ['motci. mi] 'revenge.1PL.PRs', or at a boundary with a syllable with a consonant in the coda as in obściskać [op.'ctcisk.atc] 'embrace.INF', altogether making the epenthetic analysis of - o dubious.

\section{Splitting -ość}

The split hypothesis of -o-ść consists of two statements. One is that grammatical features associated with an "unsplit" -ość, that is the nominalizer $(\mathrm{N})$, number (\#), feminine gender, and nominative case, are lexicalized by two morphemes: $-o$ and -ść. Assuming recent work on the nominal functional sequence where masculine is contained in the feminine (cf. Taraldsen 2009)

\footnotetext{
${ }^{7}$ Not to mention remarkable consonant sequences found word-internally (e.g. źdźbto

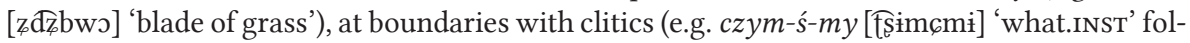
lowed by an assertive indefinite clitic marker -ś 'something' and 1pl.msc clitic - my), or across word boundaries, as in Orzechowska's (2019) example of a phrase przestępstw $z$ wstrzasajacym skutkiem 'crimes with a shocking outcome', which contains the cluster [mpstfzfsts] with ten consonants.
} 
and number comes below case (cf. Caha 2021), these ingredients come in the following order:

(12) Nom $>\#>$ Fem $>$ Msc $>$ N

Representing gender without a neuter feature in the sequence is in agreement with the analysis of neuter in three-gender languages like Polish as a lack of masculine and feminine features (e.g. Kramer 2015). The other statement submits that, in the nomina essendi class, the sequence in (12) is projected on top of an adverb that is in between the adjectival base (A) and the nominalizer $(\mathrm{N})$, as in: ${ }^{8}$

(13) Nom $>$ \# $>$ Fem $>$ Msc $>\mathrm{N}>\mathrm{Adv}>\mathrm{A}$

Under the split hypothesis, the lexical entry for - $o$ is going to have the shape like in (14), with a foot in the adverb-forming feature Adv and the nominal class feature $\mathrm{N}$, number and nominative case feature above -- the scenario made possible under the assumption of phrasal spellout. ${ }^{9}$

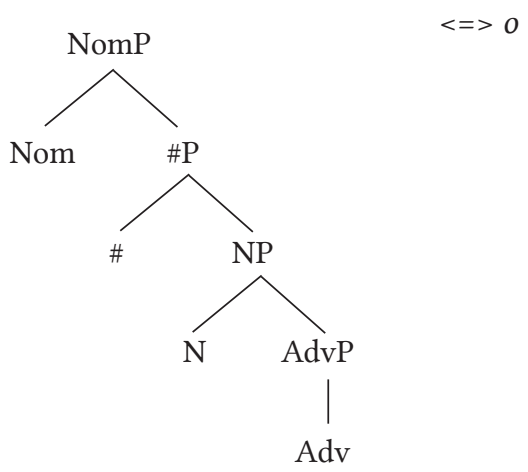

${ }^{8}$ The label Adv is used here pre-theoretically, as a stand-in for the relevant feature or features that form what is descriptively known as an adverb, a poorly understood and understudied category (though see Baker 2003 for a proposal that adverbs include a nominal ingredient added to the adjective stem, the idea further explored for Polish in Rozwadowska 2011, and Caha and Medová 2008 for a proposal to analyze Czech adverbs as adjectives with case features). Likewise, the nominal class feature $\mathrm{N}$ is a stand-in for a more contentful functor that is responsible for the formation of this class of abstract nominals. In this sense, both labels Adv and $\mathrm{N}$ are used here more descriptively than theoretically.

${ }^{9}$ The idea that spellout targets phrases rather than their terminal nodes can be traced back to McCawley (1968) and has more recently been applied in the analyses of a range of empirical domains and, in fact, analytical frameworks, including the work on pronouns in Weerman and Evers-Vermeul (2002) and Neeleman and Szendrói (2007) and, notably, the work on Nanosyntax (Starke 2009). For overviews of the spell-out mechanism in Nanosyntax see Baunaz and Lander (2018b: 16-29), Wiland (2019: 8-23), De Clercq (2020: 15-25), or Caha (2020). 
In the case of the adverb, - $o$ will lexicalize only the AdvP, the subset structure of (14). This follows from the major tenet of Nanosyntax, namely that lexically stored items are overspecified with respect to the syntactic structure they lexicalize, the idea formalized as the Superset Principle.

(15) Overspecification (Superset Principle, Starke 2009)

A lexically stored tree matches a syntactic node iff the lexically stored tree contains the syntactic node.

In other words, on the strength of the Superset Principle, (14) submits that $-o$ is a syncretic marker for adverbs and a class of nominals. ${ }^{10}$ Where we can see the superset spellout of $-o$ is a small subclass of nomina essendi with $-o$ as the only suffix on the adjectival stem, e.g. $z t-y$ 'bad' - $z t-o$ 'evil' and dobr-y 'good' - dobr-o 'goodness'. These forms are sometimes regarded in the literature as instances of conversion or 'paradigmatic derivation', where one lexeme shifts between the adjectival and nominal paradigm and selects either adjectival or nominal endings -- in our examples: the adjectival nominative $-y$ or a nominal neuter nominative -o (cf. Waszakowa 1993, Szymanek 2015: 234-235). This view, however, is complicated by forms like zim-n-y 'cold' - zim-n-o 'cold temperature' or pięk-n-y 'beautiful' - pięk-n-o 'beauty', where it is the adjectival $-n$ stem rather than the bare root that must be claimed to undergo the paradigmatic shift between adjectives and nouns. No such complication takes place if in these nouns - $o$ spells out the superset structure of (14), as shown in the lexicalization table:

\begin{tabular}{|c|c|c|c|c|c|c|c|}
\hline $\mathrm{A}(\mathrm{POs})$ & ADV & $\mathrm{N}$ & Msc & FEM & $\#$ & Nom & \\
\hline$z i m-n$ & $o$ & & & & & & 'cold temparature' \\
\hline dobr & $o$ & & & & & & 'goodness' \\
\hline
\end{tabular}

The fact that these nouns come out neuter follows from the analysis of neuter as an unmarked gender, which is interpreted for instance in Kramer (2015) as a lack of masculine and feminine. ${ }^{11}$

${ }^{10}$ Syncretism has been argued to surface as a consequence of the Superset Principle in a number of empirical domains including case (Caha 2009), class markers in Bantu (Taraldsen 2010; Taraldsen et al. 2018), spatial adpositions (Pantcheva 2011; Tolskaya 2018), aspectual prefixes (Wiland 2012), participles (Starke 2006; Taraldsen Medová and Wiland 2018; Caha and Taraldsen Medová 2020), complementizers (Baunaz and Lander 2018a), verbs (Jabłońska 2007; Taraldsen Medová and Wiland 2019), negation markers (De Clercq 2020), numerals (Wągiel and Caha, to appear), demonstratives (Lander and Haegeman 2016), wh-pronouns (Wiland 2018, 2019), and indefinite pronouns (Dekier 2021), among others.

${ }^{11}$ The fact that the $-o$ realizes neuter in this subclass immediately raises the question about its homophony with the nominative/accusative marker of neuter nouns, e.g. in miast-o 'city'. The relation between these two markers remains to be determined given the fact that the -o in examples like zim-n-o 'cold' or pięk-n-o 'beauty' comes on top of a complex adjectival base and is found with a relatively few similar examples, while the other is widely attested on 
In turn, the other lexical item, -ść, be specified for gender, number, and nominative case as in (17). ${ }^{12}$ If we follow work on gender composition like Taraldsen (2009), who argues that masculine is syntactically contained in the feminine and combine it with the fact that all -o-śc nominals are feminine, the -ść comes out to be the portmanteau marker of singular nominative feminine. ${ }^{13}$

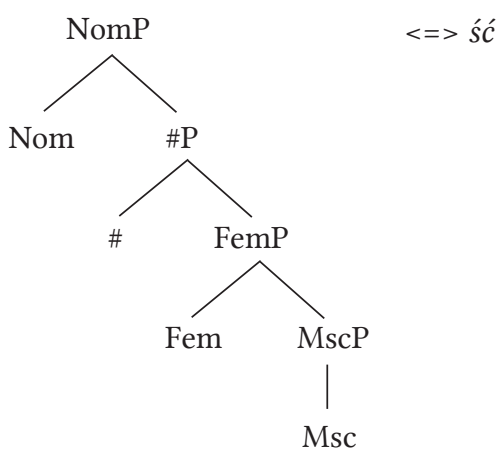

Thus, in the -o-ść nominals, - o will lexicalize the AdvP subset in adverbs and its superstructure in the nominals, which consist of the extra nominalizer followed by gender, number and case, as represented in the lexicalization table:

(18) Spellouts of -o and -ść in -o-ść nominals

\begin{tabular}{|c|c|c|c|c|c|c|c|}
\hline A (pos) & $\mathrm{ADV}$ & $\mathrm{N}$ & Msc & FEM & \# & Nom & \\
\hline jas- $n$ & $o$ & & $s c ́$ & & & & 'brightness' \\
\hline$l e k-k$ & $o$ & & $s c ́$ & & & & 'lightness' \\
\hline wys-ok & $o$ & & $s c ́$ & & & & 'height' \\
\hline mat & $o$ & & $s c ́$ & & & & 'littleness' \\
\hline mtod & $o$ & & $s c ́$ & & & & 'youth' \\
\hline
\end{tabular}

nominal roots (i.e. roots that denote objects or concepts and form nouns by directly merging with a case suffix).

${ }^{12}$ Nominative is the lowest (smallest) case in the sequence in Caha's $(2009$, et seq.) work on case decomposition, where cases lexicalize a hierarchy of privative features:

(i) [ Inst [ Loc [Dat [ Gen [Acc [Nom ] ] ]]]]

Other forms of the nominals such jasno-ści (Gen/Dat/Loc) and jasno-ściq (Inst) will lexicalize gender features jointly with higher cases projected on top of NomP.

${ }^{13}$ The feature \# is understood here as a generic number ingredient (equal to the feature "Individual" in Caha 2021), which yields a singular interpretation. If we follow Taraldsen (2018) or Caha (2021), the plural interpretation will require a more complex representation. Minimally, thus, the lexical entries for plural markers - $a$ in dobr-a 'good deeds' (as in the phrase dobra wyrzadzone zostanq wynagrodzone "the good deeds that have been done will be rewarded") but also - $i$ on top of ść in mniejsz-o-śc-i 'minorities' are portmanteaus specified for the plural feature, which is absent in the lexical entries in (14) and (17). 
Let us note that while the lexical entries in (14) and in (17) overlap with respect to \# and Nom, - $o$ and -ść do not compete for insertion since neither lexical entry is a subconstituent of the other. Such a specification, however, captures the fact that - $o$ will only be able to lexicalize \# and Nom when MscP and FemP are missing from the syntactic representation. In this context it is worth to point out that $z t-o$ 'evil' and pięk-n-o 'beauty' exist along "unremarkable" forms $z t-o-s c c$ 'anger' and piek-n-o-ść 'a beauty', which are feminine like all other -ść nouns. They can be represented jointly with structures with gapped masculine and feminine features in (19).

\begin{tabular}{|c|c|c|c|c|c|c|c|}
\hline A (POS) & ADV & $\mathrm{N}$ & Msc & FeM & \# & Nom & \\
\hline pięk-n & $o$ & & & & & & 'beauty' \\
\hline pięk-n & $o$ & & sć & & & & 'a beauty' \\
\hline$z t$ & $o$ & & & & & & 'evil' \\
\hline$z t$ & $o$ & & $s c ́$ & & & & 'anger' \\
\hline
\end{tabular}

With the split -o-ść, let us return to the few nominals based on the comparative forms listed in (4). As shown in the lexicalization table in (20), once we add the same part of the functional sequence from (13) on top of the comparative stem of the adjective, we end up with the same result as in the case of the nominals formed with the positive degree.

(20)

\begin{tabular}{|c|c|c|c|c|c|c|c|}
\hline A (CMPR) & Adv & $\mathrm{N}$ & Msc & FEM & \# & Nom & \\
\hline mni-ej-sz & $o$ & & $s c ́$ & & & & 'minority' \\
\hline$w y \dot{z}-s z$ & $o$ & & $s c ́$ & & & & 'superiority' \\
\hline więk-sz & $o$ & & $s c ́$ & & & & 'majority' \\
\hline$l \dot{z}-e j-s z$ & $o$ & & $s c^{c}$ & & & & 'lightness' \\
\hline
\end{tabular}

While the facts above fit into the split -o-ść hypothesis, let us point out two potential challenges: (i) some -o adverbs do not have a corresponding -ość nominal and (ii) there is a class of adverbs formed with - $e$ rather than -o, e.g. źl-e 'badly', dobrz-e 'well'.

The first challenge can be illustrated with examples like biat-o 'white, adv.', drog-o 'expensively' or $d u \dot{z}-o$ 'a lot, adv., for which there are corresponding adjectives but there are no corresponding -ość nominals. In this group, some nouns are formed with a (mildly) suppletive root, like biel ' whitneness' in (21a), or with a root and a nominalizer other than -ość, e.g. brzydot-a 'ugliness', dobr-oć 'goodness' in (21b); droż-yzn-a 'dearness' in (21c); or smut-ek 'sadness' in (21d). 
(21) a. biat-y 'white' - biat-o 'white, adv.' - biel 'whiteness'

b. (i) brzyd-k-i 'ugly' - brzyd-k-o 'ugly, adv.' - brzyd-ot-a 'ugliness'

(ii) dobr-y 'good' - dobrz-e 'well' - dobr-oć 'goodness'

c. drog-i 'expensive' - drog-o 'expensively' - droż-yzn-a 'dearness'

d. smut- $n-y$ 'sad' - smut-n-o 'sadly' - smut-ek 'sadness'

Even though these formatives are highly unproductive in modern Polish and show a considerable degree of idiosyncracy, we can still observe certain distributional contrasts between them and the -ość affix, which suggests that their selection is not a matter of a free lexical choice. Thus, biel in (21a) is a bare nominal root (modulo the silent singular masculine nominative suffix often represented as an abstract yer vowel, cf. Rubach 1984, 2016; Szpyra 1992), the form that is also found in verbs, a transitive biel-i-ćc 'bleach, whitewash' and an unaccusative biel-e-ć 'whiten'. ${ }^{14}$ In turn, brzyd-ot-a, dobr-oć, and wilg-oć in (21b) illustrate a distributional contrast with -ość, which attaches to entire adjectival stems (i.e. all three morphological classes of the positive degree listed in (7)-(9)), while -ot/-oć attaches directly to the root. This shows up with the $-k$ class adjectives $b r z y d-k-i$ in $(21 \mathrm{~b}(\mathrm{i}))$, where $-o t$ competes with the $-k$ affix (cf. * brzyd-k-ot-a). Unlike in the $-k$ class, -ot behaves similarly to -ość in the - $n$ class in the sense that it attaches to the complex stem (and hence does not compete with $-n$ ), as in:

(22) a. cias- $n-y$ 'tight' - cias-n-o 'tightly' - cias- $n$-ot-a 'narrowness'

b. par- $n-y$ 'muggy' - par- $n-o$ 'muggily' - par- $n$-ot- $a$ 'sticky weather'

Unlike -osśc, however, -ot can attach to verbal roots, e.g. rob-i-ć 'do' - rob-ot-a 'job'. In turn, the $-y z n$ nominalizer seen in (21c) attaches to adjectival roots of the comparative degree, as revealed by the comparative adjective $d r o \dot{z}^{-}$ $s z-y$ 'more expensive'. Since the -ość nominalizer -- as will be discussed in a greater detail shortly -- attaches to entire stems either in the positive or the comparative degree rather than bare roots, as in $w y \dot{z}$-sz-ość 'superiority' (seen in (4b)), its competition with - $y z n$ is not entirely idiosyncratic. This distributional contrast shows up also with adjectival roots that can form nominals in more than one way, as is the case with a $-k$ class adjective cien- $k-i$ 'thin' or with the adjective tęg-i 'corpulent', which has different root allomorphs in the positive and the comparative:

(23) a. cien- $k-i$ 'thin' - cien- $k$-o 'thinly' - cien- $k$-ość 'thinness'

b. cień-sz-y 'thinner' - cieni-ej 'thinner, adv.' - cien-izn-a 'poor quality'

${ }^{14}$ Let us here point out the obvious, namely that while the syncretism between (the root of) the noun biel and the roots of biel-i-ć and biel-e-ć suggests a close structural proximity, it does not necessarily indicate their structural indentity. 
(24) a. tęg-i 'corpulent, substantial' - tęg-o 'substantially' - tęg-ość 'corpulence'

b. tęz-sz-y 'more corpulent or substantial' - tęz-ej 'more substantially' $t e ̨ \dot{z}-y z n-a$ 'thews'

In $(23 \mathrm{a}, \mathrm{b})$ we see that while -ość attaches to the $k$-stem forming $c i e n$ - $k$-ość, the -izn marker (the allomorph of $-y z n$ in (21c)) attaches to the root forming a different nominal cien-izn-a. Similarly, whereas tęg-ość in (24a) instantiates the familiar pattern, tęz- $y z n-a$ in (24b) includes the bare allomorphic root of the comparative degree, which further shows the distributional contrast between -ość and the other nominalizers. ${ }^{15}$

Finally, the adverb like $d u \dot{z}-o$ 'a lot', based on the adjective $d u \dot{z}-y$ 'big', does not have a lexically corresponding nominal at all (save for conceptually related nouns like e.g. mnog-ość 'multitutde' which are based on other roots). Given a generally well-behaved pattern of the formation of -ość nominals, we can cautiously assume the lack of a nominal for $d u \dot{z}-o$ in the Polish lexicon to be an instance of an accidental rather than systematic gap.

All in all, to the extent that we can control for the existence of the alternative formatives of nomina essendi, all largely proprietary to a small number of lexemes, we are not required to make adjustments to the split - $o$-ść analysis. But the existence of $-e$ adverbs along the $-o$ adverbs does require an adjustment.

\section{Nominalized -e adverbs}

The existence of adverbs formed with - $e$ along those formed with - $o$ is problematic for the split hypothesis since in the absence of another lexical entry for the adverb, the one in (14) submits that AdvP can only be realized as - $o$ as a subset structure. In other words, with -o being the only lexical entry that can spell out AdvP, we cannot describe how - $e$ and - $o$ compete. Hence, the

${ }^{15}$ An interesting instantiation of this pattern is observed with denominal adjectives formed with $-s k$, as in:

(i) a. amator-sk-i 'amateurish' - amator(-)szcz-yzn-a 'amateurship'

b. angiel-sk-i 'English' - angiel(-)szcz-yzn-a 'English language'

c. $w t o-s k-i$ 'Italian' - wto(-)szcz-yzn-a 'mirepoix vegetables'

In this case $-y z n$ does not simply attach to the adjectival -sk stem but to a form that always includes the $s z c z$ [sts] cluster, which can be analyzed either as an allomorph of the root or of the -sk affix. Let us point out that the appearence of [sts] in the place of [sk] cannot be explained by (an intricate case of) palatalization since the output of palatalizations are soft consonants. Instead, we are dealing here with a situation that mimics iotation, which replaces $s z t d$ with hard consonants $s z t s d z$ and $s t z d$ with sts $z d z$. Unlike palatalization, iotation in Polish is unpredicatable from the phonological context and has been argued in Rubach and Booij (2001) to be best analyzed as allomorphy rather than an output of a phonological rule. 
inevitable question is if there is a distributional contrast between - $o$ and $-e$ adverbs and, if yes, can it be defined in terms of lexical entries?

What can be immediately observed about $-o$ and $-e$ adverbs is that the contrast cannot be linked to an easily identifiable syn-sem class of adjectives. For instance, both types of adverbs can correspond to attributive adjectives, as in (25a, b), and both can correspond to stage and individual level predicates, as in (26)-(27).

(25)
a. dobr-y / gęst-y jogurt good-AGR thick-AGR yogurt
b. dobrz-e/ gęst-o good-ADV thick-ADV

(26) Zachowat sie $\quad\{$ glupi-o / mądrz-e $\}$ acted.3sG REFL stupid smart stage level 'He acted stupid/smart.'

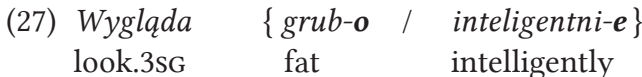
individual level 'He looks fat/intelligent.'

Likewise, if we assume Roy's (2013) classification of predicates into situation-descriptive and characterizing, we will find - $o$ and $-e$ adverbs corresponding to both classes of predicative adjectives as well, as in (28b) and (29b). ${ }^{16}$ Following Bondaruk (2015), we can distinguish between the two classes contextually:

(28) Co jest $z$ Markiem? 'What's going on with Mark?'

a. Fest goty/wściekty. ("wysoki, ${ }^{*}$ madry)

situation-descriptive 'He is naked/enraged.' ("tall, "smart)

b. got-o/ wściekl-e naked enraged

(29) Jaki jest Marek? 'What is Mark?' characterizing

a. Jest wysoki/mądry. (" goty, ${ }^{*}$ wściekty) 'He is tall/smart.' ("naked, *enraged)

b. wysok-o/maqdrz-e high smart

\footnotetext{
${ }^{16}$ Roy's (2013) typology rejects the classification of stage vs. individual level predicates. Instead, predicative adjectives fall into three types: (i) "defining", that is those whose salient property defines an individual as a class member; (ii) those that describe situations; and (iii) "characterizing", those that attribute a property to an individual. Bondaruk (2015) shows that we can distinguish only two types of predicative adjectives in Polish according to Roy's classification - situation-descriptive and characterizing - with descriptive predicates restricted to NPs, as in Mieczysława jest influencerkq 'Mieczysława is an influencer.'
} 
Instead of attributing the - $o$ vs. - $e$ contrast to a functional typology of adjectives, the choice of the adverbial marker is often presented in the literature as a competition influenced by morpho-phonology (e.g. Cyran 1967; Grzegorczykowa 1999; Wróbel 2001; Szymanek 2015). However, the morpho-phonological factors determining the selection appear to be tendencies with a varying degree of predictability.

Thus, adverbs derived from canonically adjectival roots will be predominantly formed with -o (e.g. stab-o 'weakly') unless the adjectival stem ends in $n, m, w, r, v$ or $t$, in which case the adverb will likely end in -e. ${ }^{17}$ Some examples of such adverbs are given in Table 3 .

Table 3. Examples of - $e$ adverbs based on adjectival stems ending in $n, m, w, r, v, t$

\begin{tabular}{ll}
\hline A & Adv \\
\hline pysz-n-y 'tasty' & pyszni-e 'tastily' \\
uprzejm-y 'kind' & uprzejmi-e 'kindly' \\
pod[w]y 'mean' & podl-e 'in a mean way' \\
dobr-y 'good' & dobrz-e 'well' \\
parsz-y[v]-y 'scabby' & parsz-y[v']-e 'in a scabby way' \\
obfit-y 'abundant' & obfici-e 'abundantly' \\
\hline
\end{tabular}

However, it is not difficult to find counter-examples to this tendency as for instance in the examples listed in Table 4.

Table 4. Examples of - $o$ adverbs based on adjectival stems ending in $n, m, w, r, v, t$

\begin{tabular}{ll}
\hline A & Adv \\
\hline głoś- $n-y$ 'loud' & gtoś-n-o 'loudly' \\
takom- $y$ 'gluttonous' & takom-o 'gluttonously' \\
go[w] $-y$ 'naked' & go[w]-o 'nakedly' \\
ostr- $y$ 'sharp' & ostr-o 'sharply' \\
tza-[v]- $y$ 'teary' & tza-[v]-o 'tearily' \\
bogat $y$ 'rich' & bogat-o 'richly' \\
\hline
\end{tabular}

${ }^{17}$ The adverbial $-e$ is palatalizing and exists along a non-palatalizing $e$ in Polish, the contrast sometimes described in terms of a different value of the backness feature in both segments (Gussmann 1992; Szpyra 1995) or in terms of an affix-specific diacritic (Dressler 1985; Gussmann 2007). The addition of the adverbial $-e$ to the stem results in the change of the stem-final consonants $n m r v t w$ into $n m^{j} z v^{j} t c l$, as for instance in obfit-y - obfi[tc]-e 'abundant - ly', pyszn-y - pysz[n]-e 'taste - ly', or weso[w]-y - wese[1]-e 'cheerful - ly'. 
Moreover, some adverbs can be felicitously formed with either ending, e.g. nudn-o/nudni-e 'boringly', mroźn-o/mroźni-e 'freezing', wesot-o/wesel-e 'cheerfully'.

A factor that allows us to predict the use of - $e$ more successfully is morphological complexity of the stem since $-e$ is most frequently found with adverbs formed from denominal and deverbal adjectives. This intuition is confirmed in a corpus study of the distribution of both adverb markers in Stefańczyk (2010), which was based on the sample of ca. 5000 adverbs found in Uniwersalny stownik języka polskiego [the Universal dictionary of Polish] (Dubisz 2003). As reported in the study, all 250 examples of derived adjectives formed with -iw, -liw, -ist, or -it affixes (such as e.g. placz-liw-y 'tearful' - placz-liwi-e 'tearfully', based on the noun ptacz 'cry') had -e. However, as pointed out in Grzegorczykowa (1999: 528) and Szymanek (2015: 201), -ist is equally felicitous with -o, as e.g. in fal-ist-o/fal-iści-e 'wavily'.

While derivational complexity is a positive morphological condition on the use of $-e$ also with suffixes like -aln or the participle-forming - $t$ (e.g. odczuw-aln-y 'perceptible' - odczuwalni-e 'perceptibly', okaza- $t-y$ 'spectacular' - okaza-l-e 'spectacularly'), this statement does not extend to several others affixes. These include - aw, -at, -owat, -ast (e.g. gbur-owat-y - gburowat-o 'surly'), the transgressive - ac (e.g. machaj-ac-y 'waving' - machaj$a c-o$ 'wavingly'), the adnominal -sk (e.g. amator-sk-i 'amateurish' - amator-sk-o 'amateurishly'), as well as a range of expressives (e.g. mal-ut-k-o, mal-usień-k-o, mal-uteń-k-o 'very little') (cf. Szymanek 2015: 200-201). The conclusion is that instead of a stable rule that governs the distribution of adverbial $-o$ and $-e$, we are dealing with a competition between both exponents whose result is determined by so far poorly understood interplay of more than one morpho-phonological factor. In what follows, I discuss a possible way of approaching this competition, which is in agreement with the split $-o$-ść analysis and treats $-o$ and $-e$ as allomorphs.

Let us suppose that there are two lexical entries in the Polish lexicon that include an adverb-forming layer, one in (30a)(repeated from (14)) and the other in (30b).

(30) a.
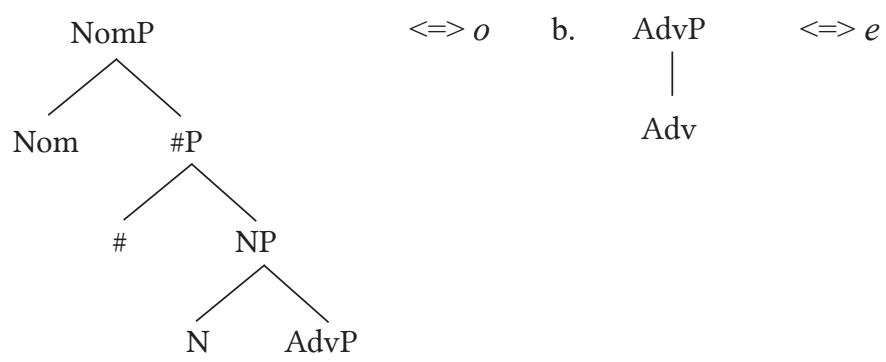
The adverbs, that is structures of the AdvP size, selecting (30a) will be lexicalized with $-o$ as a subset structure, while the $-e$ adverbs will be lexicalized with (30b). It must be emphasized that selection does not equal a competition for the lexical insertion of the exponent. If that was the case, the AdvP would be always lexicalized as - $e$ in agreement with the Elsewhere Principle:

(31) Elsewhere Principle

Where several items meet the conditions for insertion, the item containing fewer features unspecified in the node must be chosen.

The principle - sometimes informally referred to as "minimize junk" in Nanosyntax - resolves a situation where multiple lexical items are in competition for insertion into a syntactic node. Thus, if a syntactic representation to be lexicalized looks like in (32) and both lexical items in (30a) and (30b) are equally accessible at the point of exponent selection, then there is no option but to lexicalize this tree as $-e$.

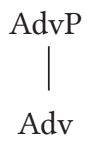

The situation is different when morpho-phonological factors influence the allomorph selection for the adverbial affix to the effect that $-o$, although a subset spellout of (30a) for AdvP, becomes preferred over $-e$ and gets selected instead. The role of morpho-phonology on allomorph selection in Polish is known to be complex and involve an interplay of stem boundary, prosody, and melody (see e.g. Rubach and Booij 2001 for an illustration on the example of iotation) and, admittedly, such task has so far not been accomplished for the adverbial allomorph. However, a hint suggesting that this may be the case is that in Polish $o$ alternates with $e$ in morpho-phonologically conditioned allomorph selection, as in e.g. nios-e - niesi-esz 'I.carry - you.carry', bior-e - bierz-e 'I.take - s/he.takes', aniot - aniel-e 'angel.Nom - angel.Voc'.

What is important for the split - $o$-ść hypothesis, is that both - $o$ and - $e$ adverbs always have -o in front of -ść (with -essć unattested in nomina essendi), as for instance in:

(33) a. mądr-y 'smart' - mądrz-e 'smartly' - mądr-o-ść 'smartness'

a. uprzejm-y 'kind' - uprzejmi-e 'kindly' - uprzejm-o-ść 'kindness'

b. podt-y 'mean' - podl-e 'meanly' - podt-o-ść 'meanness'

This is predicted by our lexical entries in $(30 a, b)$, which submit that the morpho-phonological competition for the allomorph selection between - $O$ and - $e$ can take place only for the AdvP and not for a notch bigger NP structure. This can be illustrated through a comparison of both allomorphs on 
the examples of mtod-o 'young, adv.' - mtod-o-ść 'youth' and madrz-e 'smart, adv.' - mądr-o-ść 'smartness' in the lexicalization table:

\begin{tabular}{|c|c|c|c|c|c|c|c|}
\hline $\mathrm{A}(\mathrm{POS})$ & ADV & $\mathrm{N}$ & Msc & FEM & \# & Nom & \\
\hline mtod & $o$ & & & & & & 'young, adv.' \\
\hline$m a q d r z$ & $e$ & & & & & & 'smart, adv'. \\
\hline mtod & $o$ & & $s c^{\prime}$ & & & & 'youth' \\
\hline$m a d r$ & $o$ & & $s c^{\prime}$ & & & & 'smartness' \\
\hline
\end{tabular}

Treating -o and - $e$ markers as morpho-phonologically determined allomorphs that compete only for the lexicalization of the adverb, thus, allows us to keep the idea that -o spells out $\mathrm{N}$ in both adverb classes and maintain the split -o-ść hypothesis.

\section{Conclusion}

Splitting -o-ść, traditionally described as an adjectival nominalizer, into two affixes allows us to capture the observation that there is a partial syncretism between adverbs and nomina essendi. Employing phrasal spellout and mechanisms of exponence, we have arrived at a conclusion that analyzing a class of deadjectival nouns as nominalized adverbs is a tenable task. This result, however, leads to inevitable questions about the semantic content of the adverbial ingredient, its relation to abstract nouns, as well as the extent to which such an analysis can be extended to other languages. Suffice it to say, these are open questions at this point.

\section{References}

BAKer Mark (2003). Lexical Categories: Verbs, Nouns, and Adjectives. Cambridge, UK: Cambridge University Press.

Baunaz Lena, Lander Eric (2018a). Decomposing categories syncretic with the nominal complementizer. Glossa 3(1), 31, 1-27.

BAUnAz Lena, LANDER Eric (2018b). Nanosyntax: The basics. In Exploring Nanosyntax, Lena Baunaz, Karen De Clerce, Liliane Haegeman, Eric Lander (eds.), 16-56. New York: Oxford University Press.

Bondaruk Anna (2015). Two typologies of AP predicates in Polish - a comparison. Roczniki Humanistyczne LXIII(6), 7-30.

CAHA Pavel (2009). The Nanosyntax of Case. CASTL/University of Tromsø. Ph.D. dissertation. 
CAHA Pavel (2020). Nanosyntax: Some key features. Ms., available at https://ling.auf. net/lingbuzz/004437. Accessed May 30 2021.

CAHA Pavel (2021). Modeling declensions without declension features. The case of Russian. Acta Linguistica Academica (online first), 1-41.

CAha Pavel, Medová Lucie (2008). Czech adverbs as case-marked adjectives. In Studies in Formal Slavic Phonology, Morphology, Syntax, Semantics and Information Structure, Gerhild Zybatow, Uwe Junghanns, Denisa Lenertová, Petr Biskup (eds.), 31-42. Frankfurt am Main: Peter Lang.

Caha Pavel, Taraldsen Medová Lucie (2020). Syncretism in nanosyntax and three types of passive participles in Czech. Naše řeč 103, 113-130.

Cyran Władysław (1967). Przysłówki polskie. Budowa słowotwórcza. Łódź: Łódzkie Towarzystwo Naukowe.

De Clerce Karen (2020). The Morphosyntax of Negative Markers: A Nanosyntactic Account. Berlin/Boston: Mouton De Gruyter.

DeKier Jakub (2021). Morphosyntax of specific and non-specific indefinite markers. Glossa 6(1), 70, 1-33.

Dressler Wolfgang U. (1985). Morphonology: The Dynamics of Derivation. Ann Arbor: Karoma Publishers.

Dubisz Stanisław (ed.) (2003). Uniwersalny słownik języka polskiego. Warszawa: Wydawnictwo Naukowe PWN.

GAWEŁKo Marek (1976). Sufiksy przymiotnikowe w języku polskim, niemieckim i francuskim: Studium z zakresu gramatyki kontrastywnej. Kraków: Uniwersytet Jagielloński.

Grzegorczyкowa Renata (1979). Zarys stowotwórstwa polskiego. Stowotwórstwo opisowe. $3^{\text {rd }}$ edition. Warszawa: Państwowe Wydawnictwo Naukowe.

Grzegorczykowa Renata (1999). Przysłówek. In Gramatyka Współczesnego Języka Polskiego: Morfologia, $3^{\text {rd }}$ edition, Renata Grzegorczykowa, Roman LAskowski, Henryk Wróbel (eds.), 524-535. Warszawa: Wydawnictwo Naukowe PWN.

Grzegorczykowa Renata, Puzynina Jadwiga (1999). Rzeczownik. In Gramatyka współczesnego języka polskiego: Morfologia, ${ }^{\text {rd }}$ edition, Renata GrzEGORCZYKowA, Roman LAsKowski, Henryk WróBEL (eds.), 389-468. Warszawa: Wydawnictwo Naukowe PWN.

Gussmann Edmund (1992). Back to front: Non-linear palatalisations and vowels in Polish. In Phonological Investigations, Jacek Fisiak, Stanisław Puppel (eds.), 5-66. Amsterdam: John Benjamins.

Gussmann Edmund (2007). The Phonology of Polish. Oxford: Oxford University Press. JabŁoŃska Patrycja (2007). Radical Decomposition and Argument Structure. CASTL/ University of Tromsø. Ph.D. dissertation.

Kramer Ruth (2015). The Morphosyntax of Gender. Oxford: Oxford University Press. MCCAWLEy James (1968). The role of semantics in a grammar. In Universals in Linguistic Theory, Emmon Bach, Robert Harms (eds.), 124-169. New York: Holt, Rinehart \& Winston.

LANDer Eric, Haegeman Liliane (2016). The nanosyntax of spatial deixis. Studia Linguistica 72(2), 362-427.

NeELEman Ad, SzendRő Kriszta (2007). Radical pro drop and the morphology of pronouns. Linguistic Inquiry 38, 671-714. 
Orzechowska Paula (2019). Complexity in Polish Phonotactics: On Features, Weights, Rankings and Preferences. Singapore: Springer.

Pantcheva Marina (2011). Decomposing Path: The Nanosyntax of Directional Expressions. CASTL/University of Tromsø. Ph.D. dissertation.

Post Michał (1986). Denominal Adjectivization in Polish and English. Wrocław: Wydawnictwo Uniwersytetu Wrocławskiego.

Roy Isabelle (2013). Nonverbal Predication. Copular Sentences at the Syntax-Semantics Interface. Oxford: Oxford University Press.

Rozwadowska Bożena (2011). On the status of Polish adverbs in cross-linguistic perspective. In Generative Investigations: Syntax, Morphology, and Phonology, Piotr BAŃski, Beata ŁukAszewicz, Monika Opalińska, Joanna Zaleska (eds.), 214-229. Newcastle upon Tyne: Cambridge Scholar Publishing.

RuBACH Jerzy (1984). Cyclic and Lexical Phonology: the Structure of Polish. Dordrecht: Foris.

RubAch Jerzy (2016). Polish yers: Representation and analysis. fournal of Linguistics 52, 421-466.

Rubach Jerzy, BooIj Geert E. (2001). Allomorphy in optimality theory: Polish iotation. Language 77, 26-60.

STARKE Michal (2006). The nanosyntax of participles. Lectures at the $13^{\text {th }}$ EGG summer school, Olomouc.

StARKe Michal (2009). Nanosyntax: A short primer to a new approach to language. Nordlyd 36(1), 1-6.

STEFAŃczyк Wiesław Tomasz (2010). Kilka uwag o słowotwórstwie polskiego przysłówka. Acta Universitatis Lodziensis. Kształcenie Polonistyczne Cudzoziemców 17, 223-227.

SzPYRA Jolanta (1992). Ghost segments in nonlinear phonology: Polish yers. Language 68, 277-312.

SzPyra Jolanta (1995). Three Tiers in Polish and English Phonology. Lublin: Wydawnictwo Uniwersytetu Marii Curie-Skłodowskiej.

Szymanek Bogdan (1985). English and Polish Adjectives. A study in Lexicalist WordFormation. Lublin: Redakcja Wydawnictw Katolickiego Uniwersytetu Lubelskiego.

Szymanek Bogdan (1996). Polish denominal adjectives and the problem of lexical representation. In Rules and the Lexicon: Studies in Word Formation, Edmund GussmanN (ed.), 205-219. Lublin: Redakcja Wydawnictw Katolickiego Uniwersytetu Lubelskiego.

Szymanek Bogdan (2015). A Panorama of Polish Word-Formation, $2^{\text {nd }}$ edition. Lublin: Wydawnictwo KUL.

TARALDSEN Tarald Knut (2009). Lexicalizing number and gender in Lunigiana. Nordlyd 36(1), 113-127.

TARAldsen Tarald Knut (2010). The nanosyntax of Nguni noun class prefixes and concords. Lingua 120(6), 1522-1548.

TARALDSEn Tarald Knut (2018). A recalcitrant syncretism. In The Unpublished Manuscript. A Collection of Lingbuzz Papers to Celebrate Michal Starke's 50 ${ }^{\text {th }}$ Birthday, Pavel Caha, Karen De Clerco, Guido Vanden Wyngaerd (eds.), 109-116. Available at https://ling.auf.net/lingbuzz/003993. Accessed May 30 2021. 
TARAldsen Tarald Knut, TARAldsen Medová Lucie, LAnga David (2018). Class prefixes as specifiers in Southern Bantu. Natural Language and Linguistic Theory 36(4), 1339-1394.

TARAldsen Medová Lucie, Wiland Bartosz (2018). Functional sequence zones and Slavic L $>$ T >N participles. In Exploring Nanosyntax, Lena Baunaz, Karen De ClercQ, Liliane HaEgeman, Eric LAnder (eds.), 305-328. New York: Oxford University Press.

Taraldsen Medová Lucie, Wiland Bartosz (2019). Semelfactives are bigger than degree achievements. Natural Language and Linguistic Theory 37(4), 1463-1513.

TolskayA Inna (2018). Nanosyntax of Russian verbal prefixes. In Exploring Nanosyntax, Lena Baunaz, Karen De Clerco, Liliane Haegeman, Eric Lander (eds.), 205-236. New York: Oxford University Press.

Waszakowa Krystyna (1993). Stowotwórstwo współczesnego języka polskiego. Rzeczowniki z formantami paradygmatycznymi. Warszawa: Wydawnictwa Uniwersytetu Warszawskiego.

Wągiel Marcin, CaHA Pavel (to appear). Complex simplex numerals. Acta Linguistica Academica.

Weerman Fred, Evers-Vermeul Jacqueline (2002). Pronouns and case. Lingua 112, 301-338.

Wiland Bartosz (2012). Prefix stacking, syncretism, and the syntactic hierarchy. In Slavic Languages in Formal Grammar. Proceedings of FDSL 8.5, Brno 2010, Mojmir DočEKAL, Marketa ZıкovÁ (eds.), 307-324. Frankfurt am Main: Peter Lang.

Wiland Bartosz (2018). A note on lexicalizing 'what' and 'who' in Russian and in Polish. Poznań Studies in Contemporary Linguistics 54(4), 573-604.

Wiland Bartosz (2019). The Spell-out Algorithm and Lexicalization Patterns: Slavic Verbs and Complementizers. Berlin: Language Science Press.

WróBEL Henryk (2001). Gramatyka języka polskiego. Kraków: Od Nowa.

Bartosz Wiland

Uniwersytet im. Adama Mickiewicza w Poznaniu

Wydział Anglistyki

ul. Grunwaldzka 6, 60-780 Poznań

bwiland(at)amu.edu.pl 